\title{
Geology
}

\section{Tsunami geomorphology: Erosion and deposition from the 15 November 2006 Kuril Island tsunami}

Breanyn T. Maclnnes, Joanne Bourgeois, Tatiana K. Pinegina and Ekaterina A. Kravchunovskaya

Geology 2009;37;995-998

doi: 10.1130/G30172A.1

\section{Email alerting services}

Subscribe

Permission request click www.gsapubs.org/cgi/alerts to receive free e-mail alerts when new articles cite this article

click www.gsapubs.org/subscriptions/ to subscribe to Geology

click http://www.geosociety.org/pubs/copyrt.htm\#gsa to contact GSA

Copyright not claimed on content prepared wholly by U.S. government employees within scope of their employment. Individual scientists are hereby granted permission, without fees or further requests to GSA, to use a single figure, a single table, and/or a brief paragraph of text in subsequent works and to make unlimited copies of items in GSA's journals for noncommercial use in classrooms to further education and science. This file may not be posted to any Web site, but authors may post the abstracts only of their articles on their own or their organization's Web site providing the posting includes a reference to the article's full citation. GSA provides this and other forums for the presentation of diverse opinions and positions by scientists worldwide, regardless of their race, citizenship, gender, religion, or political viewpoint. Opinions presented in this publication do not reflect official positions of the Society.

\section{Notes}

(C) 2009 Geological Society of America

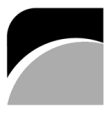

THE GEOLOGICAL SOCIETY OF AMERICA 


\title{
Tsunami geomorphology: Erosion and deposition from the 15 November 2006 Kuril Island tsunami
}

\author{
Breanyn T. Maclnnes ${ }^{1 *}$, Joanne Bourgeois ${ }^{1}$, Tatiana K. Pinegina ${ }^{2}$, and Ekaterina A. Kravchunovskaya ${ }^{2}$ \\ 'Department of Earth and Space Sciences, University of Washington, Seattle, Washington 98195, USA \\ ${ }^{2}$ Institute of Volcanology and Seismology, Far Eastern Branch Russian Academy of Sciences, 683006 Petropavlovsk-Kamchatskiy, Russia
}

\section{ABSTRACT}

The 15 November 2006 Kuril earthquake (Mw 8.1-8.4) and tsunami enabled us to collect a compelling data set of coastal geomorphic change in the Kuril Islands from $\sim 3$ months before to 9 (and 21) months after the tsunami. Our pre-tsunami and post-tsunami surveys of the islands, including four topographic profiles measured in $\mathbf{2 0 0 6}$ and reoccupied in 2007, allow us the confidence to attribute many changes to the tsunami, in spite of an absence of eyewitness accounts in the central islands. Areas with low runup, $<8 \mathrm{~m}$, underwent limited geomorphic change, primarily confined to beach or stream channels. Regions with high runup, $>\mathbf{1 5} \mathrm{m}$, underwent massive erosion that dramatically altered the coastline. Tsunami deposits roughly corresponded with the extent of tsunami runup and inundation. The amount of sediment eroded by the tsunami far outweighed the amount deposited on land in all cases studied. The tsunami was dominantly erosive in the Kuril Islands because the high-relief topography of the coastline accelerated tsunami outflow.

\section{INTRODUCTION}

To study the full impact of tsunamis on coastal geomorphology, it is essential to understand their role in both addition and removal of coastal sediment. However, most studies of tsunami geology have focused on tsunami deposition rather than erosion (Bourgeois, 2009). Yet on certain coastlines, tsunamis may be important geomorphic agents, causing long-term changes in coastal systems. Pre-tsunami and post-tsunami measurements of coastal geomorphology are necessary in order to calculate coastal change and sediment movement during a tsunami, topics of utmost interest to the tsunami community (cf. Gelfenbaum and Jaffe, 2003; Jaffe and Gelfenbaum, 2007; Huntington et al., 2007) and of broad interest to coastal geomorphologists (Dawson, 1994; Kench et al., 2008).

Tsunami-induced erosional changes of coastlines have been difficult to quantify because pre-event controls are lacking (cf. Dawson, 1994; Choowong et al., 2007; Umitsu et al., 2007). To date, the only quantified before and after studies are beach profiles and atoll-island surveys from the 2004 Indian Ocean tsunami in southwestern India and the Maldives (Kurian et al., 2006; Kench et al., 2006, 2008). In addition, Gelfenbaum and Jaffe (2003) estimated depth of erosion by the 1998 Papua New Guinea tsunami from exposed tree roots.

Despite the few quantified studies, many qualitative observations suggest that most tsunami-induced changes in coastal geomorphology are driven by erosion, during either inflow or outflow. Erosional changes to a landscape can be temporary (Kurian et al., 2006), permanent (Andrade, 1992), or continue an ongoing trend (Kench et al., 2006, 2008). Tsunamis remove vegetation and damage human-made structures (Dawson, 1994; Maramai and Tinti, 1997). Tsunami erosion causes beach retreat either as large-scale scour features or as smaller scallops (Dawson, 1994; Gelfenbaum and Jaffe, 2003; Kench et al., 2006; Kurian et al., 2006; Umitsu et al., 2007; Choowong et al., 2007). Tsunamis breach beach berms and other ridges, or erode the surface uniformly (Andrade, 1992; Dawson, 1994; Maramai and Tinti, 1997; Gelfenbaum and Jaffe, 2003; Choowong et al., 2007; Umitsu et al., 2007). They also alter drainage patterns by widening river mouths and creating

\footnotetext{
*E-mail: macinneb@u.washington.edu.
}

new drainage networks, especially from topographic lows (Andrade, 1992; Maramai and Tinti, 1997; Umitsu et al., 2007).

From a geologically fortuitous series of field seasons bracketing the 15 November 2006 Kuril Island tsunami, we have been able to quantify tsunami erosion as well as deposition. In four examples of detailed topographic profiles from before and after the tsunami, as well as in numerous post-tsunami study sites, erosion was the primary response of the coastline to the 2006 tsunami in the Kuril Islands. Dominant motion of sediment was offshore, resulting in significant alteration of coastal geomorphology in some areas.

\section{BACKGROUND}

We surveyed coastlines on the Kuril Islands in the summers of 20062008 , focusing on paleotsunami records and coastal geomorphology as a part of the multidisciplinary Kuril Biocomplexity Project. The Kurils are a volcanically active arc with many small islands in the central region (Fig. 1). Accordingly, dominant coastal geomorphologies are rocky cliffs or boulder to gravel beaches, with some sandy embayments.

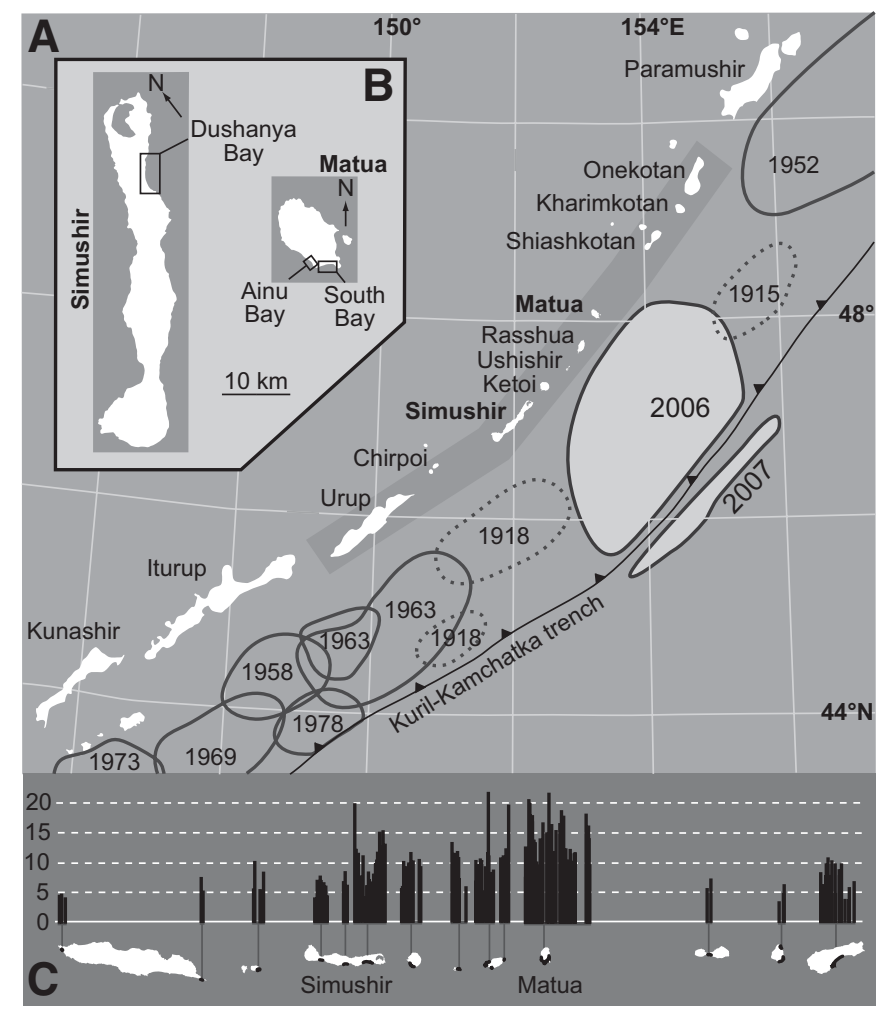

Figure 1. A: Historical tsunamigenic earthquakes on Kuril-Kamchatka trench (after Fedotov et al., 1982). The 2007 earthquake was an outerrise event in the Pacific plate; all others occurred on the PacificOkhotsk plate interface. B: Location of bays with pre-tsunami and post-tsunami topographic measurements. C: Runup elevation in meters from the 2007 and 2008 post-tsunami surveys (Table DR1; see footnote 1) for shaded area of islands in A. 
Between our first and second field seasons, the 15 November 2006 earthquake (Mw 8.1-8.4) in the Kuril-Kamchatka subduction zone (Fig. 1) produced a large tsunami (Fujii and Satake, 2008; Ammon et al., 2008). Following the November events, an outer-rise earthquake occurred on 13 January 2007 (Mw 7.9-8.1), adjacent to the 2006 rupture zone (Ammon et al., 2008; Fujii and Satake, 2008), also generating a tsunami. These tsunamis partially refocused our field efforts in 2007 and 2008 to include post-tsunami surveys and detailed examination of tsunami-caused change.

Until our post-tsunami surveys, there were no runup data from the uninhabited central Kuril Islands. However, around the Pacific Rim, tide gauges recorded tsunami amplitudes from the November 2006 event (archived for 113 locations by the National Geophysical Data Center (NGDC) Global Tsunami Database; http://www.ngdc.noaa.gov/hazard/ tsu.shtml), ranging from $<0.1 \mathrm{~m}$ (Solomon Islands) to $1.76 \mathrm{~m}$ (Crescent City, California). The January 2007 tsunami was on average three times smaller than the 2006 tsunami on tide gauges in the NGDC database.

\section{METHODS}

Our 2006 (pre-tsunami) survey focused on open embayments where paleotsunami records could be preserved, limiting quantified pre-tsunami and post-tsunami comparisons to three sandy beach-ridge plains open to the Pacific: Dushnaya Bay on northern Simushir Island, and South Bay and Ainu Bay on Matua Island (Figs. 1 and 2). All contain beach ridges $>5 \mathrm{~m}$ above mean sea level. These sites are vegetated primarily with beach rye (Elymus arenarius) and coastal-meadow grasses and flowers. All three sites were trenched by the military during World War II, which locally allowed enhancement of tsunami erosion and deposition; for the purpose of this study, we avoided these anthropogenic effects where possible.

Figure 2. Post-tsunami (2007) view of Ainu Bay, Matua (Fig. 1). Black line marks seaward extent of vegetation in 2006. Prominent driftwood logs in the foreground are $\sim 4 \mathrm{~m}$ long.

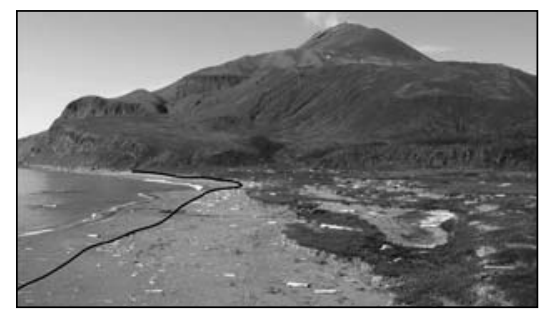

Because 10 months (September-June) passed between 2006 and 2007 field observations, we must address the question of whether the 2006 tsunami was the primary agent of observed changes. Other possible agents include the 2007 Kuril tsunami, storms, and seasonal wave regime. Seasonal effects are controlled for by our repeat survey in 2008. Moreover, there was a lack of large regional storms between field seasons (see the GSA Data Repository text, and Figs. DR2 and DR3 ${ }^{1}$ ). We reason that the January 2007 tsunami caused little change because it was much smaller and occurred when the shoreline was frozen (MacInnes et al., 2009).

Post-tsunami survey teams in the summers of 2007 and 2008 documented tsunami inundation (local maximum penetration distance), runup (elevation above mean sea level at inundation), erosion, and deposition. We surveyed 9 sites visited in 2006 or earlier, and 18 new sites, measuring in total 192 runup transects along a distance of $\sim 600 \mathrm{~km}$ (Fig. 1; Table DR1) We identified tsunami inundation and runup by the farthest inland wrackline of floatable debris. Nearfield measurements of tsunami runup average $10 \mathrm{~m}$ and range to $22 \mathrm{~m}$ (Table DR1).

${ }^{1}$ GSA Data Repository item 2009252, supplemental field observations, data, and photographs, is available online at www.geosociety.org/pubs/ft2009. htm, or on request from editing@geosociety.org or Documents Secretary, GSA, P.O. Box 9140, Boulder, CO 80301, USA.
We quantified erosional change on four 2006 topographic profiles (Figs. 1 and 3) by remeasuring the profiles using a transit and rod; to relocate we used a combination of global positioning system and landmarks such as trenches and ridge crests. On many other profiles, we described and recorded the position of erosional features, measured thicknesses of tsunami deposits, and documented the deposit's landward-most extent (Table 1). For more details on methods, see Table DR1 and MacInnes et al. (2009).
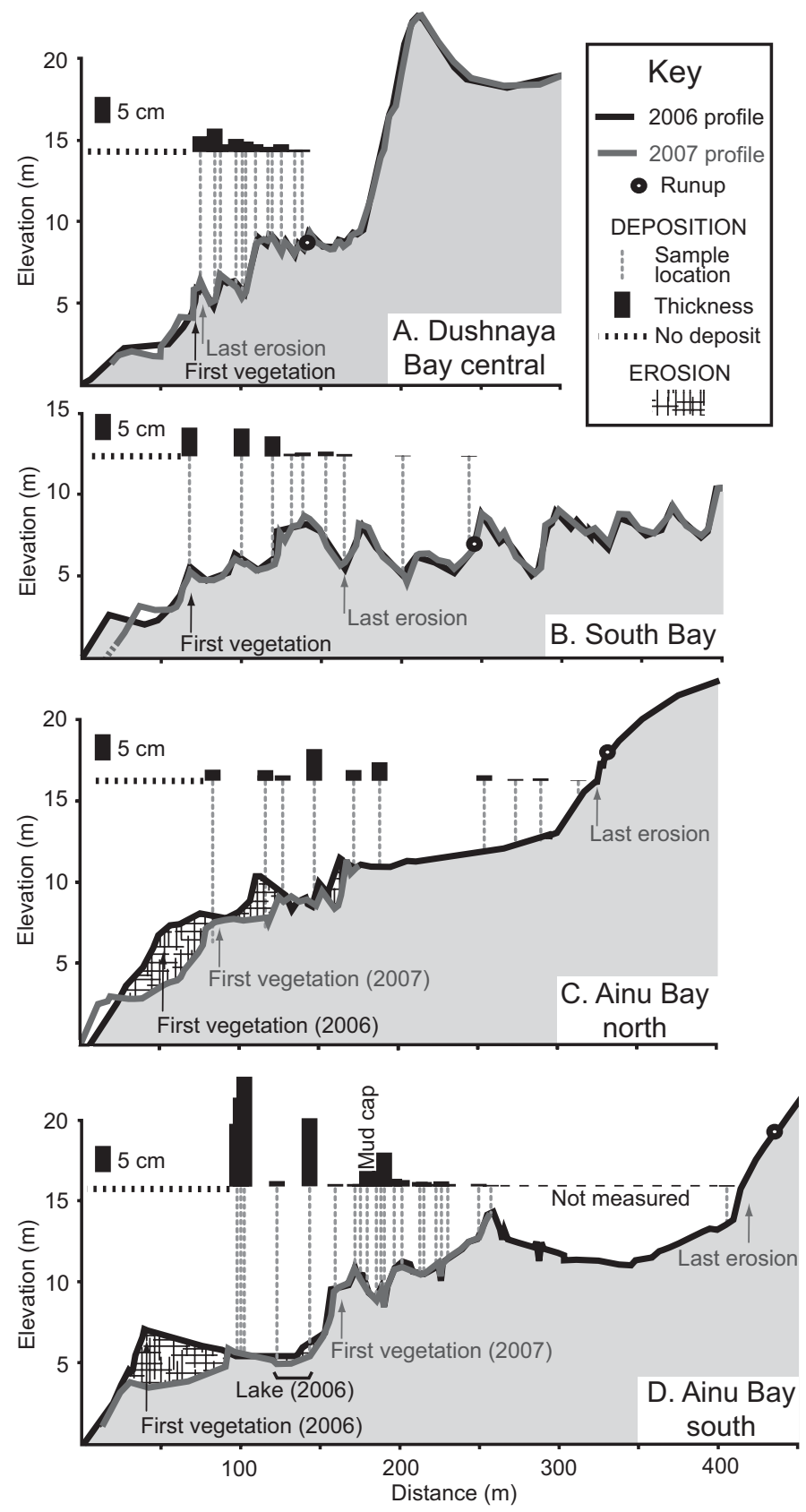

Figure 3. Before (2006) and after (2007) topographic profiles. A: From Dushnaya Bay, Simushir Island. B-D: From South Matua Island (Iocations in Figs. 1 and DR1; see footnote 1). A and B are cases of low runup and $C$ and $D$ are cases of high runup. "First vegetation" refers to seaward limit of vegetation covering a surface; in A and B, location of first vegetation did not change significantly between 2006 and 2007. In D, lake was present in 2006 but not in 2007; in area labeled "not measured," seaward-derived sand deposits were mixed with locally eroded cinders and gravel. Additional images for A-Figures DR5 and DR6; for B-Figure DR10; for C-Figures DR11-DR13; for D-Figures DR3 and DR14. 


\begin{tabular}{|c|c|c|c|c|c|c|c|c|}
\hline \multirow[b]{2}{*}{ Topographic profile* } & \multicolumn{2}{|c|}{ Water limit } & \multirow{2}{*}{$\begin{array}{c}\text { Approximate } \\
\text { deposit volume } \\
\left(\mathrm{m}^{3}\right)\end{array}$} & \multicolumn{2}{|c|}{ Deposit limit } & \multirow{2}{*}{$\begin{array}{c}\text { Approximate } \\
\text { erosion volume } \\
\left(\mathrm{m}^{3}\right)\end{array}$} & \multicolumn{2}{|c|}{ Erosion limit } \\
\hline & $\underset{\text { (m) }}{\text { Runup }}{ }^{\dagger}$ & $\begin{array}{c}\text { Inundation } \\
\text { (m) }\end{array}$ & & $\begin{array}{l}\text { Vertical }^{\dagger} \\
\text { (m) }\end{array}$ & $\begin{array}{l}\text { Horizontal } \\
\text { (m) }\end{array}$ & & $\begin{array}{l}\text { Vertical }^{\dagger} \\
\text { (m) }\end{array}$ & $\begin{array}{c}\text { Horizontal } \\
\text { (m) }\end{array}$ \\
\hline Dushnaya Bay central & 6.7 & 122 & 1.2 & 6.6 & 120 & 5 & 5.1 & 55 \\
\hline South Bay & $5.7(7.6)$ & 223 & 3.4 & $5.0(7.6)$ & 217 & 50 & $5.3(7.6)$ & 160 \\
\hline Ainu Bay north & 17.1 & 327 & 4.8 & 14.8 & 305 & 200 & 16.3 & 310 \\
\hline Ainu Bay south & 18.1 & 432 & 6.3 & 17.4 & 422 & 200 & 17.4 & 422 \\
\hline Dushnaya Bay-2 & 12.4 & 75 & 0.9 & 12.1 & 72 & $>50^{\S}$ & 11.9 & 62 \\
\hline Dushnaya Bay-6 & $4.4(10.3)$ & 106 & 1.2 & $4.4(10.3)$ & 106 & - & - & - \\
\hline Dushnaya Bay-7 & 6.3 & 139 & 1.7 & 6.3 & 139 & - & 5.9 & 122 \\
\hline Dushnaya Bay-9 & $7.3(12.6)$ & 151 & 3.0 & $7.3(12.6)$ & 151 & - & - & - \\
\hline Dushnaya Bay-12 & 6.9 & 120 & 0.9 & 5.8 & 112 & - & 3.2 & 59 \\
\hline Dushnaya Bay-109 & 9.1 & 59 & Little sand, 0.4 & 7.5 & 49 & $5^{\S}$ & 5.6 & 41 \\
\hline Dushnaya Bay-106 & 13.0 & 70 & Local gravel only & - & - & $>5^{\S}$ & 8.2 & 63 \\
\hline Dushnaya Bay-102 & 7.7 & 51 & 1.4 & 6.7 & 46 & $>5^{\S}$ & 5.1 & 37 \\
\hline Sarychevo-125 & 11.8 & 118 & 1.3 & 8.4 & 97 & - & 9.5 & 102 \\
\hline NE Rasshua-201 & 11.4 & 111 & 1.4 & 10.2 & 109 & $5^{\S}$ & 9.2 & 105 \\
\hline
\end{tabular}

Note: dash (-) indicates not measured.

*See Figure 1 or Table DR1 (see footnote 1) for locations.

tValues in parentheses indicate cases with higher topography seaward of runup.

\$Minimum estimates because beach change was not measurable without pre-tsunami topography.

\section{OBSERVATIONS}

The 2006 Kuril Island tsunami altered the coastline of the central Kurils in sandy embayments and on boulder beaches. The three sandy embayments focused on in this study, Dushnaya, South, and Ainu bays, were subject to a range of tsunami size, from low runup $(<8 \mathrm{~m})$ to high $(>15 \mathrm{~m})$, and exhibited a range of erosional and depositional features.

We observed a greater volume of erosion and deposition where runup was higher (Table 1; Fig. DR4), and fewer erosional features where runup was lower. In Dushnaya Bay, the tsunami was smaller in the center (Fig. 1C), with runup of 5-20 $\mathrm{m}$ and inundation of 40-150 $\mathrm{m}$ (Table DR1). Central Dushnaya Bay, the location of a before and after profile (Fig. 3A), recorded $\sim 6-9$ m runup and $\sim 100-150$ m inundation; erosion was limited and a sand sheet was preserved (Table 1). Runup in South Bay was low (5-8 m), with inundation of $\sim 100-200 \mathrm{~m}$ (Table DR1). We found tsunami deposits almost as far as water carried debris, with patches of erosion on vegetated beach ridges (Fig. 3B; Table 1). In Ainu Bay, runup was typically 14-20 m, with inundation up to $\sim 500 \mathrm{~m}$ (Table DR1), generating massive erosion, with erosional patches extending farther inland than we found tsunami deposits (Table 1).

\section{Sediment Removal and Erosional Features}

\section{Low Runup}

Erosion in central Dushnaya Bay can be generalized as small-scale retreat of the back-beach scarp (Fig. DR6), surficial sediment removal in areas lacking cohesive soils, and local scour associated with focused water withdrawal, especially into stream channels. At one point, the tsunami breached the seaward beach ridge. Comparison of before and after profiles (Fig. 3A) could not resolve landward retreat of the beach scarp, although nearby we measured as much as $3 \mathrm{~m}$ of retreat. The only quantifiable change on the profiles was on the unvegetated beach (Fig. 3A), where $\sim 5 \mathrm{~m}^{3}$ (per unit width) of sediment had been removed between 2006 and 2007 (Table 1).

In South Bay, before and after profiles (Figs. 3B and DR10) show a significant difference in the active beach, with $\sim 50 \mathrm{~m}^{3}$ (per unit width) of sediment missing in 2007. In beach-ridge troughs along the profile, our 2006 excavated turf blocks and some flagging tape remained virtually undisturbed in 2007. Small, shallow patches of erosion on high points as much as $160 \mathrm{~m}$ inland (Table 1) and larger ones elsewhere in South Bay were on seaward sides of beach ridges. Along the shoreline away from the profile, the tsunami removed blocks of turf off the back-beach scarp.

\section{High Runup}

Much of the erosion in Ainu Bay can be considered persistent geomorphic change (Figs. DR11-DR14). The tsunami removed $\sim 200 \mathrm{~m}^{3}$ (per unit width) of sediment along the Ainu Bay reoccupied profiles (Figs. 3C, 3D; Table 1). On both profiles, continuous, deep erosion of vegetation and sediment occurred for $\sim 160 \mathrm{~m}$ inland, including landward widening of the beach by as much as $55 \mathrm{~m}$ (Figs. 2 and 3D) via back-beach cliff retreat. The tsunami removed seaward-most beach ridges, reduced others in size, and eroded seaward-facing slopes primarily by stripping young, sandy sediment off the surface (Figs. 3C, 3D). As a particular example, a continuous scour extending over $100 \mathrm{~m}$ laterally formed on a seawardfacing slope of compact soil (at $160 \mathrm{~m}$ inland in Fig. 3C; see Fig. DR13).

Throughout Ainu Bay, smaller-scale but still dramatic erosion included patches of eroded soil and stripped vegetation as much as $5 \mathrm{~m}$ in diameter. Eroded patches were especially associated with rodent burrow networks and volcanic cinder layers below the sod, both of which facilitated soil stripping. These patches were common at the bases of slopes, some even landward of a recognizable tsunami deposit (Table 1). In areas with sandy soils, gullying and scouring were common where the tsunami was steered by low-lying topography. The tsunami also breached and drained a lake (Figs. 3D and DR14). Most indicators of flow direction, such as plunge pools and gullies, primarily recorded outflow; some, such as a flipped-over sod, recorded inflow.

\section{Sediment Deposition}

Irrespective of tsunami runup height and inundation distance, there was evidence of deposition on all studied sites (Fig. 3; Table 1). Where sand was available along the shore, the tsunami deposited a landwardthinning, continuous sheet of that sand across vegetated surfaces. Sand deposits averaged $2.5 \mathrm{~cm}$ thick (20 cm maximum) and were generally thicker in beach-ridge troughs than on crests. Along the sandy beach ridges of Dushnaya, South, and Ainu bays, the tsunami added a thin veneer of sediment, $\sim 1-6 \mathrm{~m}^{3}$ per unit width of profile (Table 1). Shorelines along boulder to gravel beaches exhibited patchy tsunami deposits of pebbly gravel and relocated cobbles and boulders generally $<1 \mathrm{~m}$ diameter. On most shorelines, the tsunami eroded and deposited blocks of sod, more abundant and larger (to $3 \mathrm{~m}$ diameter) on coarser-grained shorelines. 
Sandy tsunami deposits were nearly as extensive as the tsunami (Table 1). The maximum elevation of deposits was on average $90 \%$ of runup elevation, and never $<71 \%$ (a case with limited sand supply). The landward terminus of the deposit averaged $95 \%$ of tsunami inundation (as marked by floated debris); the horizontal difference was $<10 \mathrm{~m}$ in 9 cases, and at most $22 \mathrm{~m}$ (Table 1).

\section{Deposition versus Erosion}

Even with ubiquitous deposition, less sediment was deposited than eroded on every profile studied in detail. In the eight cases with measured volumes (per unit width) of both erosion and deposition, the amount of tsunami-transported sand preserved on the coastal plain was usually $<10 \%$ of that eroded (Table 1); only one of those profiles exhibited focused erosion (Profile 2 in Dushnaya Bay; Figs. DR1 and DR9). Even in Dushnaya Bay, where the tsunami was the smallest, erosion the least, and deposition the most extensive, about three times more sediment was removed from the coast then deposited on land.

\section{DISCUSSION AND CONCLUSIONS}

Our survey of tsunami deposits in the Kuril Islands strengthens the argument that on sandy shorelines tsunami-deposit extent can be used as a proxy for tsunami runup and inundation (Table 1; Martin et al., 2008), provided the pre-tsunami shoreline position can be reconstructed. Recent post-tsunami studies of low-relief coastlines have shown that tsunami deposits commonly extend to $90 \%$ of water runup and inundation limits (Table DR2). On the high-relief coastlines of the Kuril Islands, tsunami deposits are equally representative of onshore tsunami metrics.

The volume of tsunami erosion is related to tsunami runup, distance from shore, and topography; vegetation and local roughness can clearly be factors as well, but in our study they do not vary measurably. That the greatest erosion from tsunamis occurs closer to the shore is a common observation of post-tsunami surveys (cf. Gelfenbaum and Jaffe, 2003; Umitsu et al., 2007). Farther from the shore (hundreds of meters in the Ainu Bay case), patches of erosion typically occur where the topography generates local water acceleration, enhancing the erosive capacity of tsunamis.

Some erosional features generated by tsunamis should become preserved geomorphology. In Ainu Bay, the removal of the seaward beach ridges, breaching of a lake, and development of inland scours should all be visible for decades or centuries. Indeed, previous (undated) instances of deep coastal erosion and breached lakes can be seen in Ainu Bay stratigraphy (Fig. DR11). Even in cases of relatively low runup, breached beach ridges should remain discontinuous, and we have observed such breaches in older beach ridges in Dushnaya Bay and along the Pacific coast of Kamchatka.

Our findings agree with previous studies indicating that net direction of tsunami sediment transport is dependent on capacity of the coastline to generate backwash or offshore flow (Umitsu et al., 2007). Tsunamis flowing over low-relief coastlines (Kurian et al., 2006; Gelfenbaum and Jaffe, 2003) generated net onshore transport. On high-relief coastlines such as the Kuril Islands, tsunami backwash can be accelerated to a greater velocity than on low-relief topography, thereby generating net offshore transport. The case where a tsunami completely overtops low-relief islands, as in the 2004 Indian Ocean tsunami washing over the low-relief Maldives, is more complex (Kench et al., 2008).

For the first time, a group of tsunami geologists surveyed a coast both before and after a large tsunami. Our quantitative comparison of erosional and depositional volumes in this case showed that erosion clearly dominated deposition. Nevertheless, geologists interpreting paleotsunamis should be reassured that deposits can be a reliable proxy for tsunami runup and inundation, though the necessary paleogeographic reconstruction remains challenging, especially in light of tsunami erosion. Our data and analyses are also significant for geologists interested in understanding tsunami flow properties, in defining tsunami erosion and deposition patterns (tsunami geomorphology), and in determining coastal geologic histories in tsunami- affected regions. Moreover, while the central Kurils are currently uninhabited, this study may help explain why there are fewer coastal archaeological sites on the Pacific side of the Kurils. It also provides important information about tsunami hazard on high-relief coastlines around the world.

\section{ACKNOWLEDGMENTS}

Funding for field work was provided by the Kuril Biocomplexity Project (National Science Foundation grant 0508109, Principal Investigator Ben Fitzhugh) and by the Institute of Marine Geology and Geophysics, Far East Division, Russian Academy of Sciences, Yuzhno-Sahkalinsk, Russia (Director, Boris Levin). We thank Sergei Chirkov, Misty Nikula, Mike Etnier, and Jesse Einhorn for field assistance, Cecilia Bitz for helping us recover weather data from the region, and Brian McAdoo, Martitia Tuttle, and two anonymous reviewers for thorough reviews.

\section{REFERENCES CITED}

Ammon, C.J., Kanamori, H., and Lay, T., 2008, A great earthquake doublet and seismic stress transfer cycle in the central Kuril islands: Nature, v. 451, p. 561-566.

Andrade, C., 1992, Tsunami generated forms in the Algarve Barrier Islands: Science of Tsunami Hazards, v. 10, p. 21-34

Apel, E.V., Burgmann, R., Steblov, G., Vasilenko, N., King, R., and Prytkov, A., 2006, Independent active microplate tectonics of northeast Asia from GPS velocities and block modeling: Geophysical Research Letters, v. 33, L11303, doi: 10.1029/2006GL026077.

Bourgeois, J., 2009, Geologic effects and records of tsunamis, in Bernard, E.N., and Robinson, A.R., eds., The Sea: Volume 15, Tsunamis: Cambridge, Massachusetts, Harvard University Press, p. 55-91.

Choowong, M., Murakoshi, N., Hisada, K., Charusiri, P., Daorerk, V., Charoentitirat, T., Chutakositkanon, V., Jankaew, K., and Kanjanapayont, P., 2007, Erosion and deposition by the 2004 Indian Ocean tsunami in Phuket and Phangnga Provinces, Thailand: Journal of Coastal Research, v. 23, p. 1270-1276.

Dawson, A.G., 1994, Geomorphological effects of tsunami run-up and backwash: Geomorphology, v. 10, p. 83-94.

Fedotov, S.A., Chernyshev, S.D., and Chernysheva, G.V., 1982, The improved determination of the source boundaries for earthquakes of $M>7.75$, of the properties of the seismic cycle, and of long-term seismic prediction for the Kurile-Kamchatka Arc: Earthquake Prediction Research, v. 1, p. 153-171.

Fujii, Y., and Satake, K., 2008, Tsunami sources of the November 2006 and January 2007 Great Kuril earthquakes: Seismological Society of America Bulletin, v. 98, p. 1559-1571, doi: 10.1785/0120070221.

Gelfenbaum, G., and Jaffe, B., 2003, Erosion and sedimentation from the 17 July 1998 Papua New Guinea tsunami: Pure and Applied Geophysics, v. 160, p. 1969-1999, doi: 10.1007/s00024-003-2416-y.

Huntington, K., Bourgeois, J., Gelfenbaum, G., Lynett, P., Jaffe, B., Yeh, H., and Weiss, R., 2007, Sandy signs of a tsunami's onshore depth and speed: Eos (Transactions, American Geophysical Union), v. 88, no. 52, p. 577-578, doi: 10.1029/2007EO520001.

Jaffe, B., and Gelfenbaum, G., 2007, A simple model for calculating tsunami flow speed from tsunami deposits: Sedimentary Geology, v. 200, p. 347-361, doi: 10.1016/j.sedgeo.2007.01.013.

Kench, P.S., McLean, R.F., Brander, R.W., Nichol, S.L., Smithers, S.G., Ford, M.R., Parnell, K.E., and Aslam, M., 2006, Geological effects of tsunami on mid-ocean atoll islands: The Maldives before and after the Sumatran tsunami: Geology, v. 34, p. 177-180, doi: 10.1130/G21907.1.

Kench, P.S., Nichol, S.L., Smithers, S.G., McLean, R.F., and Brander, R.W., 2008, Tsunami as agents of geomorphic change in mid-ocean reef islands: Geomorphology, v. 95, p. 361-383.

Kurian, N.P., Pillai, A.P., Rajith, K., Murali Krishnan, B.T., and Kalaiarasan, P., 2006, Inundation characteristics and geomorphological impacts of December 2004 tsunami on Kerala coast: Current Science, v. 90, p. 240-249.

MacInnes, B.T., Pinegina, T.K., Bourgeois, J., Razhegaeva, N.G., Kaistrenko, V.M., and Kravchenovskaya, E.A., 2009, Field survey and geological effects of the 15 November 2006 Kuril tsunami in the middle Kuril Islands: Pure and Applied Geophysics, v. 166, p. 9-36, doi: 10.1007/s00024-008-0428-3.

Maramai., A., and Tinti, S., 1997, The 3 June 1994 Java tsunami: A post-event survey of the coastal effects: Natural Hazards, v. 15, p. 31-49.

Martin, M.E., Weiss, R., Bourgeois, J., Pinegina, T.K., Houston, H., and Titov, V.V., 2008, Combining constraints from tsunami modeling and sedimentology to untangle the 1969 Ozernoi and 1971 Kamchatskii tsunamis: Geophysical Research Letters, v. 35, L01610, doi: 10.1029/2007GL032349.

Umitsu, M., Tanavud, C., and Patanakanog, B., 2007, Effects of landforms on tsunami flow in the plains of Banda Aceh, Indonesia, and Nam Khem, Thailand: Marine Geology, v. 242, p. 141-153, doi: 10.1016/j.margeo.2006.10.030.

Manuscript received 24 February 2009

Revised manuscript received 9 June 2009

Manuscript accepted 15 June 2009

Printed in USA 